Article

\title{
Undergraduate Disabled Students as Knowledge Producers including Researchers: A Missed Topic in Academic Literature
}

\author{
Aspen Lillywhite and Gregor Wolbring *(D) \\ Community Rehabilitation and Disability Studies, Department of Community Health Sciences, Cumming \\ School of Medicine, University of Calgary, Calgary, AB T2N4N1, Canada; aspen.lillywhite1@ucalgary.ca \\ * Correspondence: gwolbrin@ucalgary.ca
}

Received: 29 August 2019; Accepted: 18 October 2019; Published: 23 October 2019

\begin{abstract}
Research experience is beneficial for undergraduate students for many reasons. For example, it is argued in academic literature and in reports produced by various organizations that engage with science, technology, engineering and math (STEM) education and science education that undergraduate research experience increases the graduation rate in STEM disciplines as well as the amount of students thinking about STEM careers. As such, being researchers should also be of benefit to undergraduate disabled students in all disciplines including STEM education. However, given that undergraduate disabled students encounter many problems within post-secondary education, including STEM education, undergraduate disabled students might encounter problems in becoming researchers. Policies are to be guided by knowledge and evidence. However, knowledge and evidence deficits exist in relation to the lived experience of disabled people. Undergraduate disabled students could decrease the knowledge deficit as researchers and knowledge producers. The numbers of disabled academic faculty are judged as being too low and efforts are under way to increase the number of disabled academics. Increasing the number of undergraduate disabled researchers might increase the available pool of disabled students that pursue an academic career. Given the important role research performed by undergraduate disabled students can play and given that many studies highlight problems for disabled students in post-secondary education in general, we used a scoping review approach to investigate the coverage of undergraduate disabled students as knowledge producers, including as researchers, in the academic literature. Using various search strategies, we obtained 1299 initial hits. However, only 15 had relevant content. No study investigated how undergraduate disabled students select their research topics or how they are enticed to pursue research projects outside of a course-based framework. No study looked at the linkage between being an undergraduate disabled researcher and career choices or using the obtained research skills on the undergraduate level in one's role as a community member after graduation. Our findings suggest an opportunity for many fields, ranging from disability studies to STEM education, to generate more empirical data and conceptual work on the role of undergraduate disabled students as knowledge producers including as researchers. Such studies could help to increase the numbers of undergraduate disabled students as knowledge producers, including researchers, which in turn could help to increase (a) the number of disabled academics, (b) the number of disabled students who perform research in the community after graduation, (c) the degree success of disabled students and (d) the knowledge available on the social situation of disabled people.
\end{abstract}

Keywords: knowledge production; students with disabilities; disabled students; undergraduates; governance; role; identity; career; research; researcher 


\section{Introduction}

The role and importance of undergraduate students as knowledge producers including researchers is increasingly discussed [1], including in STEM (science, technology, engineering and math) education [2,3]. Undergraduate disabled students are part of the undergraduate students' cohort, which includes the STEM education cohort. Furthermore, it is well described that disabled students face various challenges within higher education settings [4-6]. Therefore, data should be available that provides insight into the situation of undergraduate disabled students as knowledge producers, including researchers.

It is a recognized problem that the numbers of disabled academic faculty are too low (for Canada see for example [7-9]). From the literature it is known that involvement in undergraduate research increases the likelihood that students pursue graduate degrees, more research activities $[10,11]$ and consider research careers [12-14]. Therefore, increasing the pool of undergraduate disabled researchers might lead to increasing the numbers of disabled students that think about academia as a career and increase the numbers of disabled students pursuing graduate research degrees and research careers beyond the numbers reported, for example, in Canada [15].

Knowledge and evidence are expected to guide the development of policies [16]. Various sources report that academic knowledge and evidence around the social situation of disabled people that could inform policy is missing [1,17-20]. Undergraduate disabled students could be involved in generating the evidence and knowledge missing on the social situation of disabled people, given that they are experts of their lived experience [18,21-23].

The above indicates the importance of understanding the situation of undergraduate disabled students as knowledge producers, including as researchers. Therefore, the objective of our scoping review was to ascertain the coverage of undergraduate disabled students as knowledge producers including as researchers in academic literature. The following research questions were investigated; (1) how and to what extent are undergraduate disabled students mentioned as knowledge producers including research in the academic literature containing terms such as "knowledge production", "knowledge generation", "knowledge creation", "evidence production", "evidence generation" or "evidence creation"? (2) How and to what extent does the academic literature including STEM education literature investigate undergraduate disabled students as knowledge producers, including researchers? The findings are discussed through the lens of (a) knowledge governance, (b) role, identity and career development of students and (c) discussions around STEM education including three recent reports from the National Academies of Sciences, Engineering, and Medicine (USA) [2,3,24].

This study contributes to the literature on disabled people in higher education, the literature around knowledge production, knowledge governance and disabled students as researchers, the literature around STEM education and science education, and the literature engaging with undergraduate research experienc. It also benefits discourses that aim to increase the number of disabled academic faculty members [7-9] because these numbers are partly influenced by the situation of undergraduate disabled students.

\subsection{Students as Knowledge Producers Including as Researchers}

Numerous authors engage with the topic of students as knowledge producers [25,26], including as researchers $[1,27-30]$. Some authors link the roles of students as active citizens and agents of change to a role of being knowledge producers [31].

The question is: what is the role of undergraduate disabled students in relation to knowledge production? Given that academic knowledge and evidence around the social situation of disabled people that could inform policy is missing [17-19], undergraduate disabled students are in a good position to produce evidence needed on the social situation of disabled people, which might be used to influence policy and other discourses. Undergraduate disabled students are well positioned to produce knowledge that fills existing gaps and could influence change. They have access to academic information such as academic databases via their university, which most disabled people who are not 
students, do not have. However, we acknowledge that there are vast differences between countries and institutions as to how much students and faculty, in general, have access to academic literature. They can also seek out training in research methods and can be part of ethics approval processes for projects, which is something that is more difficult to do, or not at all possible for disabled people that are not linked to academia. As such, undergraduate disabled students are well situated to become knowledge producers.

Many discourses focus on members of the public producing research-based knowledge using names such as community scholar, citizen science and other terms [1,32-38]. Trained undergraduate disabled students that have experience performing research are well situated to be part of community-based and community-driven research after graduation in case they opt not to follow an academic career [1].

\subsection{Role, Identity and Career Development}

Many authors have noted that it is important to find ways to develop a research identity in students, including undergraduate students [1,39-42]. Research identity is an important aspect for students and their development [1,41,43-45]. It has an impact on career choices [43,46-49] and the personal and academic identity development of students [43].

All these reasons also apply to undergraduate disabled students. To give one example, initiatives are underway on national levels, for example within Canada, to increase the numbers of academic faculty members of marginalized backgrounds including disabled academic faculty members [7-9]. We submit that for such a goal to be successful, an increased pool of undergraduate disabled students that perform research is needed, and one must expose undergraduate disabled students to a research identity in order to entice undergraduate disabled students to pursue research on the undergraduate level. If undergraduate disabled students have a positive research experience, more undergraduate disabled students might opt to obtain a graduate thesis degree with the long-term goal of becoming academics, which they might not consider otherwise. Furthermore, it is argued that efforts are needed to entice women on the level of the primary and high school level to think about choosing certain topics to study on the university level [50]. One could make a case that disabled high school and primary school students must be exposed to a research identity.

Various authors discuss negative systemic issues faced by disabled students in higher education including accessibility, level of participation, stigmatization, lack of financial support, difficulty seeking accommodation [4,51-56], lack of awareness of faculty and peers [51,55], identity of the disabled student $[4,52,57]$, and career choice and development [58-61]. The Canadian organization, National Educational Association of Disabled Students (NEADS), produced a report in 2018 on the situation of Canadian graduate students with a disability [15] highlighting various problems faced by disabled graduate researchers.

Given these reported problems, it is necessary to investigate the situation of undergraduate disabled research students in detail. How many undergraduate disabled students exist in a given institution? Which disability do they have? What barriers exist for undergraduate disabled students to become researchers?

\subsection{STEM and Science Education}

STEM and science education have been a focus in many places for some time [2,3,24]. Studies show that interest in STEM must be generated much earlier than college or university [62-64]. There is also more to STEM and science education than teaching the scientific/technical aspects of STEM and sciences to include history, philosophy, ethics, sociology of science [65-72] and see the STSE initiative (science, technology, society and environment) [73,74]. Indeed, science education is changing in order to adapt to next generation science standards, which advocate science understanding in terms of decision making and its associated social, political, and cultural issues [75]. STEM advancements have societal implications; therein, students should know about, be able to evaluate, and be able to 
contribute to public discussions [76]. Moving beyond pure STEM education, this can "inspire creativity, open-mindedness, critical thinking, and respect for different cultures and conceptions of the world" [66] (p. 37) and increase the enjoyment and motivation of students for their studies [65,77]. Some have argued that STEM education programs should "present broader STEM career possibilities, including careers that integrate social justice, empathy, and equity matters" [78] (p. 1). Responsible research and innovation (RRI) is a concept in the European Community applied to science education to broaden its scope [79-81].

To increase students in STEM education and STEM careers, it is recommended to recruit young people to perform research [82-84], especially "undergraduate students who are members of demographic groups currently under-represented in the sciences (e.g., racial and ethnic groups, individuals from disadvantaged socioeconomic or educational backgrounds, and those with disabilities)" [82] (p. 21) and [85].

Although there has been a focus on increasing diversity and broadening participation in STEM, it is recognized that there is a gap of coverage in relation to disabled students [86-91], and there are many issues that need to be addressed [54,91,92]. Diversity is also lacking on the STEM educator level [3].

Given the above, undergraduate disabled students' research involvement is not only desirable in order to increase their success in STEM and science education, but undergraduate disabled students have a unique perspective (lived experience) through which they can generate research and knowledge on the ethical, social, legal and other aspects of STEM advancements in relation to disability. The questions are: If and how undergraduate disabled students engage in research? What contributions do undergraduate disabled research students make to STEM and science education?

\subsection{Knowledge Production Governance}

The New York Times stated already in 1853 that knowledge is power [93]. There are various modes of knowledge production: mode 1 being academic, investigator-initiated and discipline-based knowledge production and mode 2 being context-driven, problem-focused and interdisciplinary $[16,94,95]$. Knowledge production in science is a political and social process [96]. Many academics discuss the politics of knowledge production [97-103] from various perspectives including that the politics of knowledge production is problematic in relation to disabled researchers [104] and disabled people [105]. Knowledge shapes society and is in need of governance [106-109]. Knowledge governance is "the intentional achievement of societal and policy change through the purposeful production and dissemination of knowledge" [106] (p. 606). The processes of producing and selecting the knowledge to be used in policy development need a 'separate layer' of governance [110]. The question is: how, and to what extent, does the knowledge production and knowledge governance literature engage with undergraduate disabled students in their role as knowledge producers such as being researchers?

\section{Materials and Methods}

\subsection{Study Design}

Scoping studies are useful in identifying the extent of research that has been conducted on a given topic $[111,112]$ and the current understanding of a given topic. Our scoping study focuses on the extent of research that has been conducted on the role of undergraduate disabled students as knowledge producers including as researchers.

Our study employed a modified version of the stages for a scoping review outlined by Arksey and O'Malley [113], namely: identifying the research questions of the review, identifying applicable databases to search, generating inclusion/exclusion criteria, recording the descriptive quantitative results, selecting literature based on descriptive quantitative results for content coding of qualitative data, and reporting findings of qualitative analysis. 


\subsection{Identification of Research Questions}

The objective of our scoping review was to investigate the role of undergraduate disabled students as knowledge producers, evidence generators, researchers and scholars. We investigated the following research questions: (1) How and to what extent are undergraduate disabled students mentioned as knowledge producers including researchers in the academic literature containing terms such as "knowledge production", "knowledge generation", "knowledge creation", "evidence production", "evidence generation" or "evidence creation"? (2) How and to what extent does the academic literature, including the STEM education literature, investigate undergraduate disabled students as knowledge producers including researchers? The findings are discussed through the lens of (a) knowledge governance, (b) role, identity and career development of students and (c) discussions around STEM education including three recent reports from the National Academies of Sciences, Engineering, and Medicine (USA) [2,3,24].

\subsection{Data Sources and Data Collection}

To maintain a clear and feasible scope [114], we searched on June 11th, 2019, the academic databases EBSCO-HOST (an umbrella database that includes over 70 other databases itself) and Scopus (which incorporates the full Medline database collection) with no time restrictions. These two databases contain journals that cover a wide range of topics from areas of relevance to answer the research questions; for example, the disability studies journals: disability and society, disability studies quarterly, journal of literary and cultural disability studies and review of disability studies: an international journal (2004-2014). The databases also contained many highly ranked journals focusing on education including STEM and science education and special education.

Furthermore, we also used the search engines, without restrictions, on the webpages of the Canadian Journal of Disability Studies (CJDS) and the Review of Disability Studies: An International Journal (RDS) because EBSCO-HOST and Scopus do not cover CJDS, and only covered the RDS journal until 2014.

We searched for scholarly peer reviewed journals in EBSCO-HOST and we searched for reviews, peer reviewed articles, conference papers, and editorials in Scopus.

We performed the following search strategies (Table 1) in EBSCO-HOST and Scopus. The same search terms were used for CJDS and RDS but the search engine of CJDS only searched the abstracts and for RDS we downloaded every paper after 2014 and searched the full text for the terms.

Table 1. Search strategies used.

\begin{tabular}{|c|c|}
\hline Strategy & Search Terms Used \\
\hline Strategy 1a & "undergraduate researcher" in the abstract \\
\hline Strategy $1 b$ & "undergraduate research experience" in the abstract \\
\hline Strategy $1 \mathrm{c}$ & 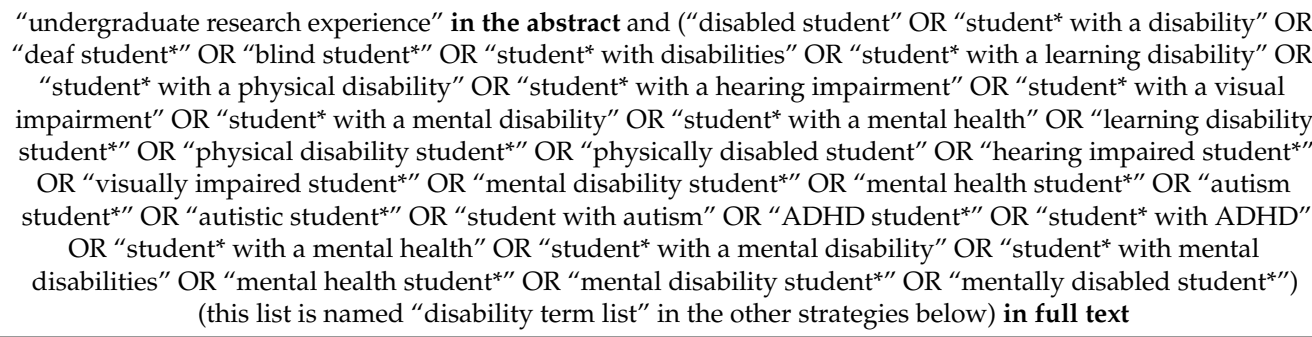 \\
\hline Strategy $1 \mathrm{~d}$ & $\begin{array}{l}\text { "undergraduate research experience" in the abstract and ("disabled" OR "disability" OR "deaf" OR "blind" OR } \\
\text { "disabilities" OR "impairment" OR "autism" OR "autistic" OR "ADHD") in the full text }\end{array}$ \\
\hline Strategy $2 \mathrm{a}$ & $\begin{array}{l}\text { "knowledge production" or "knowledge generation" or "knowledge creation" or "evidence production" or } \\
\text { "evidence generation" or "evidence creation" together with "undergraduate*" in the abstract }\end{array}$ \\
\hline Strategy $2 b$ & $\begin{array}{l}\text { "knowledge production" or "knowledge generation" or "knowledge creation" or "evidence production" or } \\
\text { "evidence generation" or "evidence creation" AND "undergraduate" }\end{array}$ \\
\hline
\end{tabular}


Table 1. Cont.

\begin{tabular}{|c|c|}
\hline Strategy & Search Terms Used \\
\hline Strategy 3a & "researcher*" together with the term "undergraduate" AND "disability term list" in the abstract \\
\hline Strategy $3 b$ & "research" together with the term "undergraduate" AND "disability term list" in the abstract \\
\hline Strategy 3c & 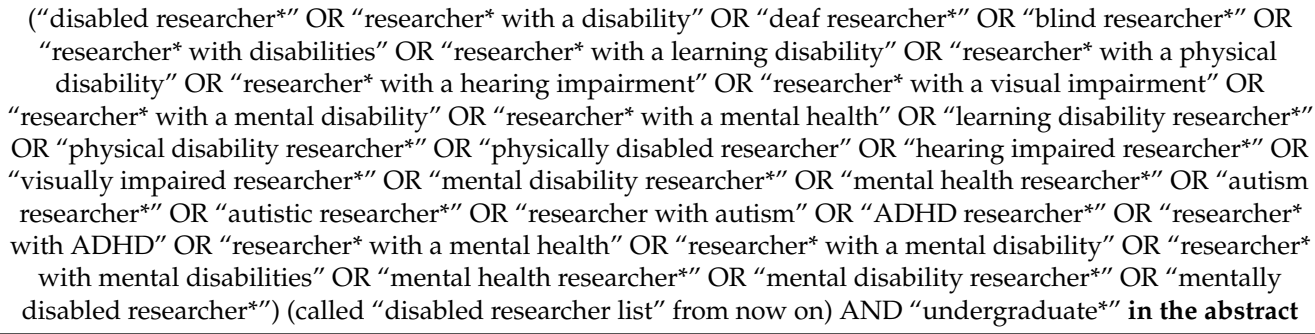 \\
\hline Strategy $3 d$ & "disabled researcher list" (see strategy 3c) AND "undergraduate" in the abstract \\
\hline Strategy 4a & "disability term list" AND "research" AND "STEM education" in the abstract \\
\hline Strategy $4 \mathrm{~b}$ & "disabled researcher list" AND "STEM education" in the abstract \\
\hline Strategy $4 \mathrm{c}$ & "disability term list" AND "research" AND "science education" in the abstract \\
\hline Strategy $4 \mathrm{~d}$ & "disabled researcher list" AND "science education" in the abstract \\
\hline
\end{tabular}

\subsection{Data Analysis}

To answer the research questions, we first obtained hit counts for our search term combinations (Figure 1) employing a descriptive quantitative analysis approach $[115,116]$. We then uploaded the full texts and abstracts obtained from the four search strategies into the qualitative analysis software ATLAS.Ti $8^{\mathrm{TM}}$ for a directed qualitative content analysis [115-118]. We used a directed content analysis to add knowledge about the phenomenon of undergraduate disabled students as knowledge producers, including researchers, that "would benefit from further description" [115] (p. 1281). As to the coding procedure, we familiarized ourselves with the content of all articles and abstracts and identified relevant data [118]. We then independently identified and clustered the themes based on meaning, repetition and the research questions $[115,119]$.

\subsection{Trustworthiness Measures}

Trustworthiness measures include confirmability, credibility, dependability, and transferability [120-122]. Differences in codes and theme suggestions of the qualitative data were few and discussed between the authors (peer debriefing) and revised as needed [121]. Confirmability is evident in the audit trail made possible by using the memo and coding functions within ATLAS.Ti $8^{\mathrm{TM}}$ software. As for transferability, our methods description gives all required information for others to decide whether they want to apply our keyword searches on other data sources such as the grey literature, or other academic literature or other languages or whether they want to perform more in-depth.

\subsection{Limitations}

The search was limited to two academic databases and English language literature. As such, the findings are not to be generalized to the whole academic literature, non-academic literature, or non-English literature. These findings, however, allow conclusions to be made within the parameters of the searches.

\section{Results}

Of the 15 relevant documents, ten were articles and five were conference proceedings. Seven were published in 2017, three in 2018, two were published in 2011, 2015 and 2019 and one in 2014. As to the authors of the articles, one article had authors based in the UK, one in Taiwan and the other 13 had authors based in the USA. 


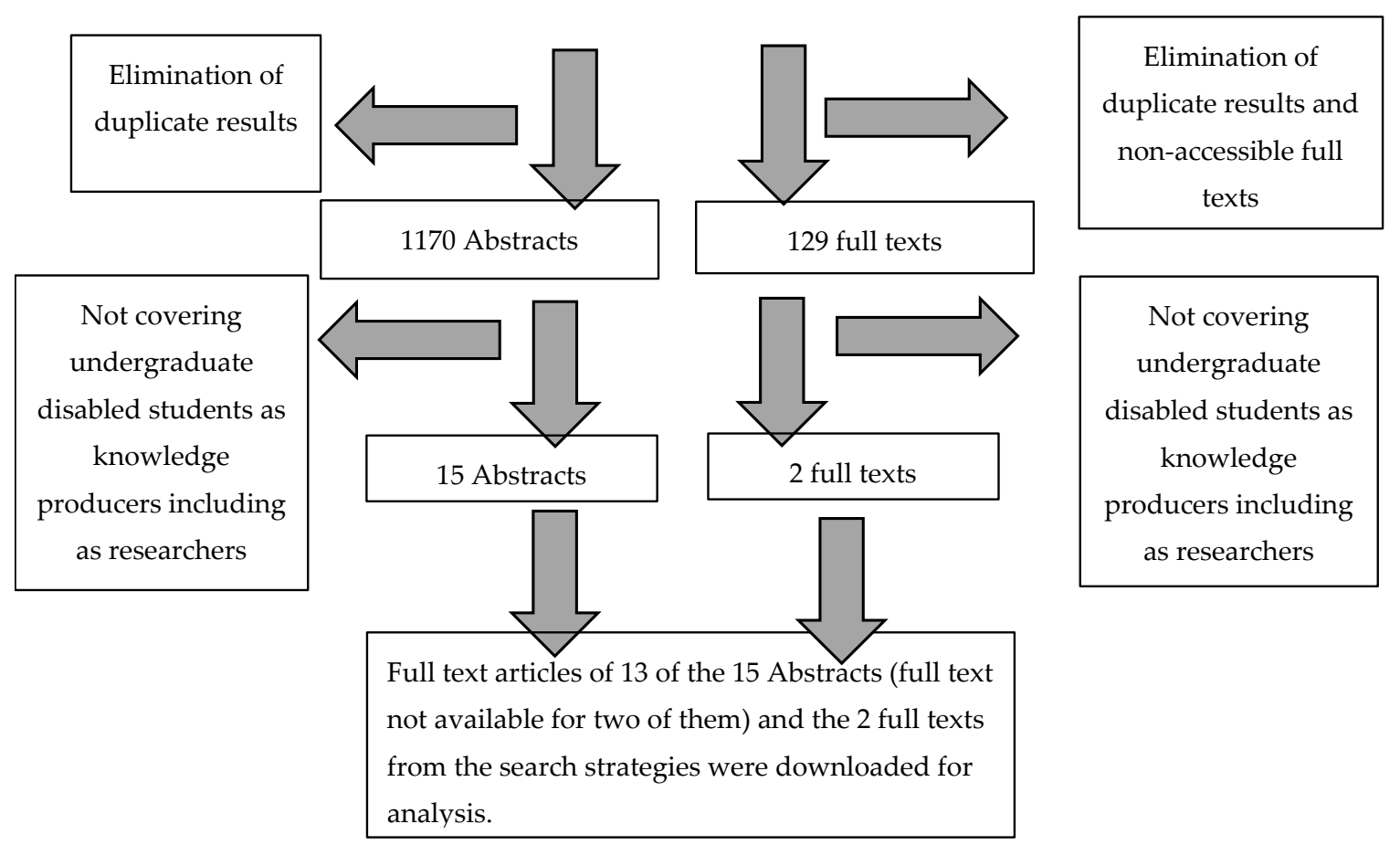

Figure 1. Flow chart of the selection of academic abstracts and full text articles for qualitative analysis.

\subsection{Strategies $1 a-d$}

Of the 226 abstracts obtained with strategy 1a, only four were relevant. Three covered undergraduate deaf research students [123-125]. Within the full text of these three articles the authors of one article argued that "Increasing DHH [deaf and hard of hearing] student representation in the STEM fields is critical to diversify the STEM workforce in the United States and to provide lucrative career opportunities for DHH graduates" [124] (p. 31), whereby one "strategy toward accomplishing this goal is to create positive undergraduate research experiences for DHH students" [124] (p. 31). Two articles indicated that communication problems between deaf and hard of hearing students on the one side and hearing students, mentors and faculty on the other side, negatively impacts the undergraduate research experience [123,124]. Two articles argued that a lack of awareness of Deaf culture in general, and by mentors in particular, impacts deaf and hard of hearing students undergraduate research experience $[123,125]$. One article recommended the creation of a national coalition of deaf and hard of hearing scholars and that such coalition should have as one main focus the increase of deaf and hard of hearing students in STEM [125]. The fourth article covered undergraduate students with disabilities in general within the context of STEM education [126]. The article focused on understanding the experience and benefit of undergraduate research. The authors argue that benefits include self-identity improvement, improved graduation rate and more students pursuing graduate degrees [126]. They found that performing undergraduate research had a positive effect on degree completion, increased likelihood of joining STEM graduate degrees and obtaining STEM jobs [126].

Of the 399 abstracts obtained with strategy $1 \mathrm{~b}$, only two covered undergraduate disabled students of which both were already mentioned under strategy 1a $[123,124]$. Searching the full text of the 399 abstracts for the disability list terms (Strategy 1c) only generated one non-relevant article, which mentioned a disability related term in the reference list. Strategy $1 \mathrm{~d}$ generated 17 more hits but no article had relevant content.

\subsection{Strategies $2 a$ and $b$}

Within the 182 abstracts obtained with strategy 2a, 25 abstracts engaged with undergraduate students as researchers, but not one abstract covered undergraduate disabled students as researchers. 
Of the 78 full text articles obtained with strategy $2 b$, not one engaged with undergraduate disabled students as knowledge producers including as researchers.

\subsection{Strategies $3 a-d$}

Of the 23 abstracts obtained with strategy $3 a$, two had relevant content. One abstract engaged with undergraduate autistic research students discussing "the challenges and benefits of including autistic participant researchers" [127] (p. 84) reflecting on the experience in their own research project. Another abstract discussed the experience of the "National Science Foundation funded Research Experience for Undergraduates (REU) Site for students with ADHD", focusing on the experience of one fourth grade teacher and one ninth grade teacher spending six weeks working with undergraduate student researchers with ADHD in engineering labs [128]. The authors argued that the program improved "teachers' perceptions of students with ADHD" [128] (p. 1) and made problems with the education system, such as high risk of "academic failure and disinterest in pursuing higher education," visible [128] (p. 1). They concluded that ADHD students can thrive in a research environment and that such research environment is beneficial for students with ADHD" [128]. The rest of the abstracts outlined many issues undergraduate disabled student face in STEM and career trajectory but did not cover undergraduate disabled students as knowledge producers including as researchers (e.g., [86,129]).

Of the 291 abstracts obtained with strategy $3 b$, only 10 new abstracts with relevant content were obtained. Four abstracts with relevant content where already covered under the other strategies $[123,125,127,128]$. Of the six abstracts, two indicated the barriers to research fieldwork for mobility impaired students in geoscience degrees $[130,131]$. Two reflected on the positive effects of involving deaf and hard of hearing undergraduate students in chemical and biological research activities [132,133]. One concluded that involving undergraduate disabled students in research increased students' interest in engineering research, in general, and graduate studies in engineering, and also increased the sense of belonging in engineering [134]. Finally, the Quality of Life Technology (QoLT) Research Experience for Undergraduates (REU) program was mentioned and that the program positively effected the transformation of students "from dependent to independent thinkers" [135] (p. 1). It was furthermore highlighted that there were personal benefits for students and that the numbers of minority graduate students in STEM graduate degrees increased [135]. The article also highlighted the creation of a program called Experiential Learning for Veterans in Assistive Technology and Engineering (ELeVATE) funded by the National Science Foundation to help "transition veteran disabled students into the field of STEM" [135] (p. 1).

Of the six abstracts obtained with strategy 3c, only one [128], already covered elsewhere, had relevant content.

Of the 33 downloadable full text obtained with strategy $3 d$, one full text with relevant content covered deaf and hearing researcher partnerships and the skills both need in order to work together [136].

\subsection{Strategies $4 a-d$}

We obtained 20 hits with strategy 4a; 0 hits with strategy 4b; 23 hits with strategy 4c and 0 hits with strategy $4 \mathrm{~d}$. However only three hits contained relevant content.

Two articles stated that undergraduate research experience is important for increasing the presence of disabled students in STEM education [137,138].

Authors of one article argued that undergraduate research experience is one way to provide a STEM identity and sense of belonging [139]. This study provided the results of a survey that focused on the relationship between deaf mentees and their research mentors whereby deaf community capital, asking for accommodations, and communication access emerged as problems between deaf students and non-deaf mentors [139].

\section{Discussion}

Our findings reveal that only 15 academic abstracts engaged with undergraduate disabled students as knowledge producers, including as researchers. 


\subsection{Role, Identity and Career Development}

Being a knowledge producer, including being a researcher, is a role increasingly linked to undergraduate students [1,140-142]. According to Palmer "an undergraduate education needs to ensure students graduate with higher order skills that prepare them for today's increasingly complex society and economy, and academic dispositions that are developed particularly well through research and inquiry-based learning opportunities" [43] (p. 415). As such, the lack of data we found around the role of undergraduate disabled students as knowledge producers including as researchers is problematic. An in-depth understanding of the barriers experienced by undergraduate disabled students in being knowledge producers, including being researchers, how they decide to be or not to be knowledge producers including researchers, and how they decide what topic to produce knowledge including research on or not is needed.

Post-secondary institutions should do more to educate citizens for democracy [143], and many articles cover the role of students as active citizens and agents of change [144]. Some articles link the roles of active citizen and knowledge producer [31]. Our data suggest a deficiency in the educational efforts to produce undergraduate disabled students that see themselves as active citizens and agents of change through knowledge production.

Many authors have noted that it is important to find ways to develop a research identity in students including undergraduate students [1,39-42]. Research identity is an important aspect of personal and academic identity development of students $[1,41,43-45]$ and has an impact on career choices $[43,46-49]$. Identity is also an important aspect for disabled students [4,52]. The lack of engagement with undergraduate disabled students as knowledge producers, including researchers, that we found suggests an opportunity to add the knowledge producer, including researcher, identity to undergraduate disabled students' personal and professional identities.

Canadian initiatives are underway with the goal to increase the numbers of academic faculty members of marginalized backgrounds including disabled academic faculty members [7-9]. From the literature it is known that involvement in undergraduate research increases the likelihood that students pursue graduate degrees and more research activities [10,11] and consider research careers [12-14]. Therefore, increasing the pool of undergraduate disabled students that perform research should have a positive impact on the goal of increasing the numbers of disabled academics. Our data suggest that not enough undergraduate disabled students think about being an academic as a career trajectory. As such, undergraduate disabled students need exposure to a research identity so the undergraduate disabled student can decide early on whether research interests them and to think about an academic career trajectory. But for this to be successful, more data is needed as to why not more undergraduate disabled students select an academic trajectory, including academic research and how best to fix the problem.

Mentorship is often highlighted as an important aspect of research experience of undergraduate students $[145,146]$ including underrepresented groups [147]. Within our data, mentorship was identified as a problem for undergraduate disabled students $[123,125]$.

Seguda and Mohorn self-identifying as black female and Latino scientists [147] made clear that what they picked career-wise (becoming science educators) and their goals (being an agent of change and to help others) was linked to their identity. They argued that minority faculty experience negative bias from non-minority faculty as well as from their students, and minority faculty also experienced judgment regarding what research matters, which is also something that is argued in relation to the impact of motivated reasoning on disabled people [20]. They identified various problems related to mentorship including total lack of mentorship [147].

"David: I stopped going to my honors advisor after that first semester where I did well taking 3 courses in math and science. Hearing all the horror stories of undergraduate research-mainly of being asked to do menial tasks like wash dishes, or to clean up the lab-I was ok not taking these 'opportunities,' nor did I really feel I would benefit from them". [147] (p. 55) 
We need many studies and best practice implementations around mentorship and undergraduate disabled researchers. We need studies that produce data on what to do about the lack of disabled academics as mentors especially if the body/mind ability difference from the norm of the academic must be the same as the students. As two abstracts of our data indicated for deaf undergraduate research students and non-deaf mentors $[123,125]$, mentors need a lot of knowledge to understand the barriers disabled students face in becoming academics.

We need ways to support a culture of being a disabled academic (disabled academic networks within and between universities), which is something that is missing in and between universities we would say. We need disabled academics to be part of studies and not always be excluded. One study published June 2019 for example argued that underrepresented faculty members do most of the work in terms of diversity and inclusion activities at universities on top of their academic work [148]. However, they did not mention disabled academics.

The well-known fact that efforts to increase the participation of women in STEM careers must start long before the university stage [50] suggests that efforts to increase undergraduate disabled researchers must also start before the university level and that one has to expose disabled students in high school and earlier to such option as is done with girls.

\subsection{STEM and Science Education}

We found little engagement with undergraduate disabled student's involvement in research, which is highly problematic given that undergraduate research experience increases success in STEM and science education $[2,149,150]$. Furthermore, undergraduate disabled students have a unique perspective through which they can generate research and knowledge on the ethical, social, legal and other aspects of STEM and science advancements. We cover the two aspects separately below.

\subsubsection{Undergraduate Researchers, Success in STEM and Science Education and STEM and Science Careers}

Many authors argue that there must be more of a focus on broadening participation of disabled people in STEM and science education [86,87,89-91]. Various groups such as the Canadian organization, National Educational Association of Disabled Students (NEADS), engage with the topic of how to educate disabled people on STEM issues and how to increase the numbers of disabled people in STEM careers $[151,152]$.

Undergraduate research experience is important to STEM education especially for underrepresented groups, including disabled people [2,3]. Our data support the notion that little has been done to study the effect of undergraduate research experience of disabled people on their STEM career and how to increase the undergraduate research experience of undergraduate disabled students. Our findings provide empirical evidence of a gap that needs to be filled. The gap fits with a lack of specific content around undergraduate disabled students that is present in a recent major report on STEM education and undergraduate research experience [2]. The report does not go into details or provide a separate section for disabled people but mentions them as part of underrepresented groups.

Interest in STEM must be generated as early as the preK-3 curriculum [62-64]. As such, undergraduate disabled research students could also be part of diversifying school views on STEM and disabled people. Furthermore, it might be prudent to introduce the research identity as early as preK-3 stage to the disabled student.

\subsubsection{Research on Disability Contributes to STEM and Science Education}

STEM and science education should include not only scientific/technical aspects of STEM [24,65-71,153,154] but also societal aspects. For example, the STSE initiative (science, technology, society and environment) reflects this view [65,72]. 
STEM advancements, such as the development of assistive technologies, impact disabled people in positive ways but also in negative ways. For example, there is currently a debate around precision genetic engineering [155] and the danger of automatization and robotics on employment of disabled people [156].

Furthermore, various terms can be used to label disabled people [157] and the language used is linked to the social identity of that person [158] (for example, patient being a medical identity and Deaf or neurodiverse being a non-medical identity). With any given social identity comes expectations of the role of that person within society [158], and this identity influences how a problem is defined, along with what solution is sought. As such, how disabled people are portrayed and what role is linked to them in STEM discourses impacts how STEM is advanced and what problems are identified in relation to them.

Undergraduate disabled students have a unique lived experience, and as such, are well positioned to perform research projects that look at the impact (e.g., social, medical, political, economic, legal) of STEM advancements on disabled people, which could be used within STSE education and STEM education covering societal aspects of STEM advancements.

Undergraduate disabled research students generating new knowledge on the impact of STEM advancement on disabled people fits with the next generation of science standards, which advocate science understanding in terms of decision making and its social, political, and cultural issues [73-75]. Data produced by undergraduate disabled research students would augment the ability of STEM education students and others "to make wise personal choices and contribute to public debate in the future" [76] (p. 1210), "inspire creativity, open-mindedness, critical thinking, and respect for different cultures and conceptions of the world" [66] (p. 37), and might make a case for broader STEM career possibilities, including careers that integrate social justice, empathy, and equity matters [78].

Responsible research and innovation (RRI) is a concept developed within the EU for science education to increase social and ethical issues within scientific and technological research and innovation [79-81]. Undergraduate disabled research students could contribute to this goal by providing data on what RRI must think about in relation to disabled people, to be socially and ethically sensitive and inclusive in relation to disabled people.

Emmanuel Levina's premise that education is about learning from the other, rather than about the other, is proposed as a suitable framework for STSE science education [157]. Therein, learning from undergraduate disabled research students might be warranted.

\subsection{Knowledge Production and Its Governance}

Knowledge governance is "the intentional achievement of societal and policy change through the purposeful production and dissemination of knowledge" [106] (p. 606). Knowledge governance is needed [110] and enables collective action and the solving of societal problems [106]. We submit that knowledge created by undergraduate disabled students would enrich knowledge governance discourses. However, our findings suggest that knowledge governance discussions do not include and enable undergraduate disabled students as co-shapers of social and policy change through knowledge production. Knowledge creation and mobilisation enables governance [107], and governance mechanisms impact knowledge processes [108]. As such, it is within the scope of knowledge governance to engage with the gap in the literature we found.

Frameworks are developed to help understand knowledge production [109]. However, such frameworks lack engagement when understanding how undergraduate disabled students generate knowledge and what type of knowledge they want to generate. Indeed, we did not find any study that engaged with the question of how undergraduate disabled students select research topics and why they decided to pursue research on the undergraduate level in the first place. 
"The role of [Higher Educational Institutes] is not only to provide access for students with disabilities," but also to "build knowledge of disability into all academic spheres, and to produce graduates who are able to understand and deal with disability issues in their professional lives" [159] (p. 2). Undergraduate disabled research students could be the ones building this body of knowledge. Barnes argued that there will be more disabled students in higher education as the 21st century progresses [160]. However, this has neither led to an increase in engagement with undergraduate disabled students as knowledge producers including as researchers nor a satisfactory level of numbers of disabled academics so far.

Our findings suggest an opportunity for educational bodies to foster the development of undergraduate disabled students as knowledge producers including as researchers. Indeed, not once did the literature present direct dialogue (i.e., interviews) with undergraduate disabled students to better understand how they view themselves and whether knowledge producer including researcher emerges as a self-identity. Knowledge production "can support the full and equal rights of disabled people, barrier removal and an inclusive society that welcomes the whole range of human diversity" [161] (p. 66). As such, undergraduate disabled students could be an important group as knowledge producers including researchers.

There are concerns and problems with knowledge production and evidence generation governance [106,162] including in educational settings [163]. One problem being what type of knowledge and evidence is produced by whom [20,163-165].

Our data demonstrate the lack of engagement with undergraduate disabled students as knowledge producers and evidence generators, including as researchers. Numerous and varied problems with knowledge production were identified in relation to disabled people namely who generates what knowledge and evidence, what knowledge and evidence related to disabled people is seen as 'valid' and 'real' $[1,20,166]$, and how does one deal with behaviors such as motivated reasoning where one only reads knowledge fitting ones belief [20]. Further knowledge governance research is needed that is situated at the intersection of knowledge and evidence production, motivated reasoning and the role of disabled people. Given our data, more research is needed on the role undergraduate disabled research students can play to decrease the negative effect of motivated reasoning on disabled people [20].

\section{Conclusions and Future Research}

Our findings suggest that there is a significant gap in academic literature around undergraduate disabled students as knowledge producers including as researchers. Within the 15 articles found, none moved beyond individual level engagement. None looked at the role of undergraduate disabled student researchers as a group or provided data that would allow one to understand how undergraduate disabled students decide to go or not to go to a research based graduate program, how undergraduate disabled students select academia as a career, how they pick their research topic for undergraduate research, or how they are enticed to perform research. Furthermore, most of our data derived from STEM related example with none focusing specifically on research activities within social sciences, humanities or education. We find this surprising and problematic. There are many problems disabled students encounter as part of their university experience: accessibility, stigmatization, lack of financial support, difficulty seeking accommodation, lack of awareness of faculty and peers, and the identity of the disabled student [4,51-61]. Disabled graduate students indicated less satisfaction in all questions related to research experience than non-disabled graduate students in a 2018 study by the National Educational Association of Disabled Students (NEADS) [15]. Various articles by graduate disabled students or academic disabled researchers highlight barriers to their research activities [167-170]. Furthermore, it is noted that:

"People with disabilities have a stake in the academic deliberations and research produced within philosophy of education. This scholarship affects disabled people not only insofar as it represents them and their experiences, sometimes inadequately or inaccurately, but also because it frequently omits consideration of ability diversity in the first place. Yet whether 
and how one sees oneself reflected in research and in knowledge production bears directly on one's social identity and status as an epistemic agent" [171] (p. 224) and that a "person's disability should not prevent them ... from the opportunity to contribute to academic scholarship". [171] (p. 224)

Therefore, one should expect that undergraduate disabled students also encounter difficulties in becoming researchers whereby the problems might be different to other undergraduate students. As such, we expected more literature that engaged with the case of undergraduate disabled students as knowledge producers including researchers. The lack of coverage might be because there are so many problems for disabled undergraduate students to have good course related university experiences that one does not think beyond that case. Another possibility is that the accommodation policies and procedures discussed in relation to undergraduate disabled students might be mostly applicable to course-based situations and not research activities. Finally, given that there are not many disabled research academics to start with and that Canada, for example, only in recent years started to think about how to change this, thinking about undergraduate disabled students as researchers simply might not have been on the horizon of researchers, given all the other problems one could research on in relation to disabled students that have not been solved yet.

Our findings suggest opportunities for further research and conceptual work to fill the gaps. One could generate qualitative data by interviewing disabled undergraduate students, disabled graduate students, disabled and non-disabled academics involved in research and teaching, and disabled high school students and high school teachers to name a few groups.

Many disabled students obtain jobs in the community after graduation and do not pursue an academic career. At the same time-discourses, such as citizen science [32], democratizing science [172], Do-it-yourself science (DIY science) [173], action research [174,175], community science [176] and being a community researcher [177], a community scholar [1] focus on increasing the role of community members and citizens as researchers. Therefore, one could investigate the topic of undergraduate disabled students performing research in the community during and after their degree, which is a topic that has been engaged with in relation to undergraduate students [1]. Our findings suggest opportunities for education efforts focusing on undergraduate disabled students as researchers to entice them to think about becoming graduate students and academics early on, and to give them the knowledge on how to do research, so they could be part of research endeavors through university and after graduation.

Author Contributions: Conceptualization, G.W. and A.L.; methodology, G.W. and A.L.; formal analysis, G.W. and A.L.; investigation, G.W. and A.L.; data curation G.W. and A.L; writing-original draft preparation A.L.; writing-review and editing, G.W. and A.L.; supervision, G.W.; project administration, G.W.; funding acquisition, G.W.

Funding: This research was funded by Government of Canada, Canadian Institutes of Health Research, Institute of Neurosciences, Mental Health and Addiction ERN 155204 in cooperation with ERA-NET NEURON JTC 2017.

Acknowledgments: We would like to thank Glenn Dolphin for comments on an earlier version of the manuscript.

Conflicts of Interest: The authors declare no conflicts of interest.

\section{References}

1. Wolbring, G.; Djebrouni, M.; Johnson, M.; Diep, L.; Guzman, G. The Utility of the "Community Scholar" Identity from the Perspective of Students from one Community Rehabilitation and Disability Studies Program. Interdiscip. Perspect. Equal. Divers. 2018, 4.

2. National Academies of Sciences Engineering and Medicine. Undergraduate Research Experiences for STEM Students: Successes, Challenges, and Opportunities; The National Academies Press: Washington, DC, USA, 2017. [CrossRef]

3. National Academies of Sciences Engineering and Medicine. Indicators for Monitoring Undergraduate STEM Education; The National Academies Press: Washington, DC, USA, 2018. [CrossRef] 
4. Hutcheon, E.J.; Wolbring, G. Voices of disabled post secondary students: Examining higher education disability policy using an ableism lens. J. Divers. High. Educ. 2012, 5, 39-49. [CrossRef]

5. Moola, F.J. The Road to the Ivory Tower: The Learning Experiences of Students with Disabilities at the University of Manitoba. Qual. Res. Educ. 2015, 4, 45-70.

6. Kearney, A. The right to education: What is happening for disabled students in New Zealand? Disabil. Stud. Q. 2016, 36. [CrossRef]

7. Natural Sciences and Engineering Research Council of Canada. 2019 Made-in-Canada Athena SWAN CONSULTATIONs. Available online: http://www.nserc-crsng.gc.ca/Forms-formulaires/Swan-2019_eng.asp (accessed on 26 August 2019).

8. Government of Canada. Equity, Diversity and Inclusion Requirements and Practices. Available online: http://www.chairs-chaires.gc.ca/program-programme/equity-equite/index-eng.aspx (accessed on 26 August 2019).

9. Government of Canada. Advisory Committee on Equity, Diversity and Inclusion Policy. Available online: http://www.chairs-chaires.gc.ca/program-programme/equity-equite/advisory_committee_on_equityeng.aspx (accessed on 26 August 2019).

10. Hathaway, R.S.; Nagda, B.A.; Gregerman, S.R. The relationship of undergraduate research participation to graduate and professional education pursuit: An empirical study. J. Coll. Stud. Dev. 2002, 43, 614-631.

11. Willis, D.A.; Krueger, P.S.; Kendrick, A. The influence of a research experiences for undergraduates program on student perceptions and desire to attend graduate school. J. STEM Educ. Innov. Res. 2013, 14, 21.

12. Carpi, A.; Ronan, D.M.; Falconer, H.M.; Lents, N.H. Cultivating minority scientists: Undergraduate research increases self-efficacy and career ambitions for underrepresented students in STEM. J. Res. Sci. Teach. 2017, 54, 169-194. [CrossRef]

13. Villarejo, M.; Barlow, A.E.; Kogan, D.; Veazey, B.D.; Sweeney, J.K. Encouraging minority undergraduates to choose science careers: Career paths survey results. CBE Life Sci. Educ. 2008, 7, 394-409. [CrossRef]

14. Grunert, M.L.; Bodner, G.M. Finding fulfillment: Women's self-efficacy beliefs and career choices in chemistry. Chem. Educ. Res. Pract. 2011, 12, 420-426. [CrossRef]

15. National Educational Association of Disabled Students (NEADS). Comparison of Specific Populations of Graduate Students with Disabilities Using 2016 CGPSS Data. Available online: https://www.neads.ca/en/ about/media/CombinedReport_Nov28.pdf (accessed on 26 August 2019).

16. Hessels, L.K.; Van Lente, H. Re-thinking new knowledge production: A literature review and a research agenda. Res. Policy 2008, 37, 740-760. [CrossRef]

17. Chataika, T.; McKenzie, J.A. Global institutions and their engagement with disability mainstreaming in the south: Development and (dis) connections. In Disability in the Global South. International Perspectives on Social Policy, Administration, and Practice; Springer: Cham, Switzerland, 2016; pp. 423-436.

18. World Health Organization. World Report on Disability. Available online: http://www.who.int/disabilities/ world_report/2011/en/index.html (accessed on 26 August 2019).

19. Berghs, M.; Atkin, K.; Graham, H.; Hatton, C.; Thomas, C. Implications for Public Health Research of Models and Theories of Disability: A Scoping Study and Evidence Synthesis. Available online: http://eprints.whiterose.ac.uk/ 103434/1/FullReport_phr04080.pdf (accessed on 26 August 2019).

20. Wolbring, G.; Djebrouni, M. Motivated Reasoning and Disabled People. Interdiscip. Perspect. Equal. Divers. 2018, 4 .

21. World Health Organization. WHO Global Disability Action Plan 2014-2021. Available online: http://apps.who. int/iris/bitstream/10665/199544/1/9789241509619_eng.pdf (accessed on 26 August 2019).

22. Hamraie, A.; Fritsch, K. Crip Technoscience Manifesto. Catal. Fem. Theory Technosci. 2019, 5, 1-33. [CrossRef]

23. Abbott, D.; Porter, S. Environmental hazard and disabled people: From vulnerable to expert to interconnected. Disabil. Soc. 2013, 28, 839-852. [CrossRef]

24. National Academies of Sciences Engineering and Medicine. The Integration of the Humanities and Arts with Sciences, Engineering, and Medicine in Higher Education: Branches from the Same Tree; The National Academies Press: Washington, DC, USA, 2018. [CrossRef]

25. Shin, S.; Cho, E. The culturally situated process of knowledge production in a virtual community: A case of hypertext analysis from a university's class web discussion boards. Curr. Issues Comp. Educ. 2003, 6, 51-60. 
26. Tan, S.C.; Hung, D.; Scardamalia, M. Education in the knowledge age-Engaging learners through knowledge building. In Engaged Learning with Emerging Technologies; Springer: Berlin/Heidelberg, Germany, 2006; pp. 91-106.

27. Thomson, P.; Gunter, H. From 'consulting pupils' to 'pupils as researchers': A situated case narrative. Br. Educ. Res. J. 2006, 32, 839-856. [CrossRef]

28. Bucholtz, M.; Lopez, A.; Mojarro, A.; Skapoulli, E.; VanderStouwe, C.; Warner-Garcia, S.J.L.; Compass, L. Sociolinguistic justice in the schools: Student researchers as linguistic experts. Lang. Linguist. Compass 2014, 8, 144-157. [CrossRef]

29. Kerfeld, C.A.; Simons, R.W. The undergraduate genomics research initiative. PLoS Biol. 2007, 5, e141. [CrossRef]

30. Hunter, J.; O'Brien, L. How do high school students create knowledge about improving and changing their school? A student voice co-inquiry using digital technologies. Int. J. Stud. Voice 2018, 3, 1-32.

31. Loh, C.E. Literacy, place, and pedagogies of possibility, by Barbara Comber. Lang. Educ. 2018, 32, 79-82. [CrossRef]

32. Kullenberg, C.; Kasperowski, D. What is citizen science?-A scientometric meta-analysis. PLoS ONE 2016, 11, e0147152. [CrossRef]

33. Evans, R.; Plows, A. Listening without prejudice? Re-discovering the value of the disinterested citizen. Soc. Stud. Sci. 2007, 37, 827-853. [CrossRef]

34. Breen, J.; Dosemagen, S.; Warren, J.; Lippincott, M. Mapping Grassroots: Geodata and the structure of community-led open environmental science. ACME Int. J. Crit. Geogr. 2015, 14, 849-873.

35. Whyte, W. Participatory Action Research; Sage Publisher: Thousand Oaks, CA, USA, 1991.

36. McFarlane, H.; Hansen, N. Inclusive methodologies: Including disabled people in participatory action research in Scotland and Canada. In Participatory Action Research Approaches and Methods: Connecting People, Participation and Place; Routledge: London, UK; New York, NY, USA, 2007; pp. 88-94.

37. Leadbeater, B. How disability studies and ecofeminist approaches shape research: Exploring small-scale farmer perceptions of banana cultivation in the Lake Victoria region, Uganda. Disabil. Glob. South 2017, 2, 752-776.

38. Tanabe, M.; Pearce, E.; Krause, S.K. "Nothing about us, without us": Conducting participatory action research among and with persons with disabilities in humanitarian settings. Action Res. 2017, 16, 280-298. [CrossRef]

39. Saddler, T.N. Socialization to Research: A Qualitative Exploration of the Role of Collaborative Research Experiences in Preparing Doctoral Students for Faculty Careers in Education and Engineering. Available online: https://vtechworks.lib.vt.edu/bitstream/handle/10919/27615/SaddlerETD.pdf? sequence=1 (accessed on 26 August 2019).

40. Adedokun, O.A.; Zhang, D.; Parker, L.C.; Bessenbacher, A.; Childress, A.; Burgess, W.D. Understanding how undergraduate research experiences influence student aspirations for research careers and graduate education. J. Coll. Sci. Teach. 2012, 42, 82-90.

41. McGinn, M.K.; Lovering, M. Researcher Education in the Social Sciences: Canadian Perspectives about Research Skill Development. Available online: http://citeseerx.ist.psu.edu/viewdoc/download;jsessionid= B46E8A2178040289B062FC5DCCDC5DD9?doi=10.1.1.548.9879\&rep=rep1\&type=pdf (accessed on 26 August 2019).

42. Purdy, J.P.; Walker, J.R. Liminal Spaces and Research Identity The Construction of Introductory Composition Students as Researchers. Pedagogy 2013, 13, 9-41. [CrossRef]

43. Palmer, R.J.; Hunt, A.N.; Neal, M.; Wuetherick, B. Mentoring, undergraduate research, and identity development: A conceptual review and research agenda. Mentor. Tutoring Partnersh. Learn. 2015, 23, 411-426. [CrossRef]

44. Malachowski, M.; Osborn, J.M.; Karukstis, K.K.; Ambos, E.L. Enhancing and Expanding Undergraduate Research: A Systems Approach: New Directions for Higher Education, Number 169; John Wiley \& Sons: San Francisco, CA, USA, 2015.

45. Hunter, A.B.; Laursen, S.L.; Seymour, E. Becoming a scientist: The role of undergraduate research in students' cognitive, personal, and professional development. Sci. Educ. 2007, 91, 36-74. [CrossRef]

46. Lent, R.W.; Brown, S.D.; Hackett, G. Social cognitive career theory. In Career Choice and Development; Duane Brown and Associates, Ed.; Wiley: San Francisco, CA, USA, 2002; pp. 255-311.

47. Prince, J.P. Influences on the career development of gay men. Career Dev. Q. 1995, 44, 168-177. [CrossRef] 
48. Tang, M.; Fouad, N.A.; Smith, P.L. Asian Americans' career choices: A path model to examine factors influencing their career choices. J. Vocat. Behav. 1999, 54, 142-157. [CrossRef]

49. Gushue, G.V.; Scanlan, K.R.; Pantzer, K.M.; Clarke, C.P. The relationship of career decision-making self-efficacy, vocational identity, and career exploration behavior in African American high school students. J. Career Dev. 2006, 33, 19-28. [CrossRef]

50. Sadler, P.M.; Sonnert, G.; Hazari, Z.; Tai, R. Stability and volatility of STEM career interest in high school: A gender study. Sci. Educ. 2012, 96, 411-427. [CrossRef]

51. Holloway, S. The experience of higher education from the perspective of disabled students. Disabil. Soc. 2001, 16, 597-615. [CrossRef]

52. Low, J. Negotiating identities, negotiating environments: An interpretation of the experiences of students with disabilities. Disabil. Soc. 1996, 11, 235-248. [CrossRef]

53. Love, T.S.; Kreiser, N.; Camargo, E.; Grubbs, M.E.; Kim, E.J.; Burge, P.L.; Culver, S.M. STEM Faculty Experiences with Students with Disabilities at a Land Grant Institution. J. Educ. Train. Stud. 2015, 3, 27-38. [CrossRef]

54. White, J.L. Early Interest in STEM and Career Development: An Analysis of Persistence in Students with Disabilities. J. Educ. Res. Policy Stud. 2013, 13, 63-86.

55. Barnar-Brak, L.; Lectenberger, D.; Lan, W.Y. Accommodation strategies of college students with disabilities. Qual. Rep. 2010, 15, 411-429.

56. Olney, M.F.; Kim, A. Beyond adjustment: Integration of cognitive disability into identity. Disabil. Soc. 2001, 16, 563-583. [CrossRef]

57. Abes, E.S.; Wallace, M.M. “People See Me, But They Don't See Me": An Intersectional Study of College Students With Physical Disabilities. J. Coll. Stud. Dev. 2018, 59, 545-562. [CrossRef]

58. Alston, R.J.; Hampton, J.L. Science and engineering as viable career choices for students with disabilities: A survey of parents and teachers. Rehabil. Couns. Bull. 2000, 43, 158-164. [CrossRef]

59. Lee, A. Students with Disabilities Choosing Science Technology Engineering and Math (STEM) Majors in Postsecondary Institutions. J. Postsecond. Educ. Disabil. 2014, 27, 261-272.

60. Fleming, A.R.; Fairweather, J.S. The role of postsecondary education in the path from high school to work for youth with disabilities. Rehabil. Couns. Bull. 2012, 55, 71-81. [CrossRef]

61. Lindsay, S.; Duncanson, M.; Niles-Campbell, N.; McDougall, C.; Diederichs, S.; Menna-Dack, D. Applying an ecological framework to understand transition pathways to post-secondary education for youth with physical disabilities. Disabil. Rehabil. 2018, 40, 277-286. [CrossRef] [PubMed]

62. Carroll, K.; Scott, C. Creating STEM Kits for the Classroom. Sci. Child. 2017, 55, 36-41. [CrossRef]

63. Tims, H.; Turner Iii, G.E.; Cazes, G.B.; Marshall, J.M. Junior cyber discovery: Creating a vertically integrated middle school cyber camp. In Proceedings of the ASEE Annual Conference and Exposition, San Anotonio, TX, USA, 9-10 June 2012.

64. Cunningham, S.L.; Kunselman, M. University of Washington and partners' program to teach middle school students about neuroscience and science careers. Acad. Med. J. Assoc. Am. Med Coll. 1999, 74, 318-321. [CrossRef]

65. Steele, A. Troubling STEM: Making a case for an ethics/STEM partnership. J. Sci. Teach. Educ. 2016, 27, 357-371. [CrossRef]

66. Berkovitz, J. Some Reflections on "Going Beyond the Consensus View" of the Nature of Science in K-12 Science Education. Can. J. Sci. Math. Technol. Educ. 2017, 17, 37-45. [CrossRef]

67. Bazzul, J. Tracing "ethical subjectivities" in science education: How biology textbooks can frame ethico-political choices for students. Res. Sci. Educ. 2015, 45, 23-40. [CrossRef]

68. Bell, R.L.; Lederman, N.G. Understandings of the nature of science and decision making on science and technology based issues. Sci. Educ. 2003, 87, 352-377. [CrossRef]

69. Blackley, S.; Sheffield, R. Appraising the E in STEM education: Creative alternatives to "engineering". Int. J. Innov. Sci. Math. Educ. 2015, 23, 1-10.

70. Keiler, K.C.; Jackson, K.L.; Jaworski, L.; Lopatto, D.; Ades, S.E. Teaching broader impacts of science with undergraduate research. PLoS Biol. 2017, 15, e2001318. [CrossRef] [PubMed]

71. Newell, C. Whose values, which ethics?: Science education and the civil society. [This paper is an abridged version of a Keynote address presented to the Australian Science Teacher's Association (ASTA) Conference, Wrest Point Convention Centre, Hobart, July 2002.]. Aust. Sci. Teach. J. 2003, 49, 6. 
72. Kim, M.; Roth, W.-M. Rethinking the ethics of scientific knowledge: A case study of teaching the environment in science classrooms. Asia Pac. Educ. Rev. 2008, 9, 516-528. [CrossRef]

73. Gunckel, K.L.; Tolbert, S. The imperative to move toward a dimension of care in engineering education. J. Res. Sci. Teach. 2018, 55, 938-961. [CrossRef]

74. Horsma, G. High school genetics education and Alzheimer disease. Genet. Test. 1999, 3, 147-153. [CrossRef] [PubMed]

75. Gill, P.S. Genetic Superheroes and Socioscientific issues in Science Education. Natl. Teach. Educ. J. 2015, 8, 67-68.

76. Gelamdin, R.B.; Alias, N.; Attaran, M. Students' and teachers' perspectives on biotechnology education: A review on publications in selected journals. Life Sci. J. 2013, 10, 1210-1221.

77. Ramsey, K.; Baethe, B. The keys to future STEM careers: Basic skills, critical thinking, and ethics. Delta Kappa Gamma Bull. 2013, 80, 26-33.

78. McGee, E.; Bentley, L. The equity ethic: Black and Latinx college students reengineering their STEM careers toward justice. Am. J. Educ. 2017, 124, 1-36. [CrossRef]

79. de Vocht, M.; Laherto, A. Profiling Teachers Based on Their Professional Attitudes towards Teaching Responsible Research and Innovation. Eur. J. Sci. Math. Educ. 2017, 5, 271-284.

80. de Vocht, M.; Laherto, A.; Parchmann, I. Exploring teachers' concerns about bringing Responsible Research and Innovation to European science classrooms. J. Sci. Teach. Educ. 2017, 28, 326-346. [CrossRef]

81. Laherto, A.M.P.; Kampschulte, L.; de Vocht, M.; Blonder, R.; Akaygün, S.; Apotheker, J. Contextualizing the EU's "responsible research and innovation" policy in science education. Eurasia J. Math. Sci. Technol. Educ. 2018, 14, 2287-2300. [CrossRef]

82. Goode, C.T.; Britner, S.L.; Gagné, P.; Pecore, J.L.; Demetrikopoulos, M.K.; Williams, B.A.; Carruth, L.L.; DeHaan, R.L.; Frantz, K.J. Scientific research self-efficacy among undergraduates: Current contexts and approaches for measurement. In Self-Efficacy in School and Community Settings; Britner, S., Ed.; Nova Science Publishers, Hauppauge: New York, NY, USA, 2014; pp. 21-52.

83. Erdogan, N.; Bozeman, T.D. Models of project-based learning for the 21st century. In A Practice-Based Model of STEM Teaching: STEM Students on the Stage (SOS); Sahin, A., Ed.; Sense Publishers: Rotterdam, The Netherlands, 2015; pp. 31-42. [CrossRef]

84. Ramos, R.L.; Esposito, A.W.; O'Malley, S.; Smith, P.T.; Grisham, W. Undergraduate neuroscience education in the US: Quantitative comparisons of programs and graduates in the broader context of undergraduate life sciences education. J. Undergrad. Neurosci. Educ. 2016, 15, A1. [PubMed]

85. Weekes, N.Y. Diversity in neuroscience. We know the problem. are we really still debating the solutions? J. Undergrad. Neurosci. Educ. 2012, 11, A52-A54.

86. Groen, C.J.; McNair, L.D.; Paretti, M.C.; Simmons, D.R.; Shew, A. Exploring professional identity development in undergraduate civil engineering students who experience disabilities. In Proceedings of the ASEE Annual Conference and Exposition, Salt Lake City, UT, USA, 10-11 October 2018.

87. Lawler, J.; Joseph, A.; Greene, M. Diversity in Information Systems: Increasing Opportunities in STEM for Capable Students with Developmental and Intellectual Disabilities. Inf. Syst. Educ. J. 2018, 16, 13-26.

88. Leung, M.A. Developing Sustainable Methods for Broadening Participation by Transforming Mainstream Science and Technology Communities Through the Normalization of Inclusion. Am. Behav. Sci. 2018, 62, 683-691. [CrossRef]

89. Cady, E.; Fortenberry, N. Metrics to assess broadening participation in STEM. In Proceedings of the ASEE Annual Conference and Exposition, Pittsburgh, PA, USA, 22-25 June 2008.

90. Hawley, C.E.; McMahon, B.T.; Cardoso, E.D.; Fogg, N.P.; Harrington, P.E.; Barbir, L.A. College graduation to employment in STEM careers: The experience of new graduates at the intersection of underrepresented racial/ethnic minority status and disability. Rehabil. Res. Policy Educ. 2014, 28, 183-189. [CrossRef]

91. Slaton, A.E. Body? What body? Considering ability and disability in STEM disciplines. In Proceedings of the ASEE Annual Conference \& Exposition, Atlanta, GA, USA, 23-26 June 2013; pp. 1-15.

92. White, J.L.; Mitchell, S.K. Career certainty and persisting interest in STEM: An analysis of underrepresented groups. J. Women Minorities Sci. Eng. 2013, 19, 47-66. [CrossRef]

93. New York Times. Free Education and Industrial Schools-Lecture of Alexander Jones. New York Daily Times (1851-1857), 19 February 1853; 6. 
94. Gibbons, M.; Limoges, C.; Nowotny, H.; Schwartzman, S.; Scott, P.; Trow, M. The New Production of Knowledge: The Dynamics of Science and Research in Contemporary Societies; Sage: London, UK, 1994.

95. Gray, M.; Schubert, L. Sustainable social work: Modelling knowledge production, transfer, and evidence-based practice. Int. J. Soc. Welf. 2012, 21, 203-214. [CrossRef]

96. Fuchs, S.; Turner, J.H. What makes a science'mature'?: Patterns of organizational control in scientific production. Sociol. Theory 1986, 4, 143-150. [CrossRef]

97. Andrade, K.; Cushing, L.; Wesner, A. Science Shops and the US Research University: A Path for Community-Engaged Scholarship and Disruption of the Power Dynamics of Knowledge Production. In Educating for Citizenship and Social Justice; Springer: Berlin/Heidelberg, Germany, 2018; pp. 149-165.

98. Huijer, M.; Janze, I. Democratic transactions in the life sciences: A gender democratic labyrinth. Eur. J. Women's Stud. 2005, 12, 9-29. [CrossRef]

99. McCormick, S. Democratizing science movements: A new framework for mobilization and contestation. Soc. Stud. Sci. 2007, 37, 609-623. [CrossRef]

100. Mohan, G.; Yanacopulos, H. Governing and democratising technology for development: Bridging theory and practice. Sci. Public Policy 2007, 34, 233-238. [CrossRef]

101. Guston, D. Understanding 'anticipatory governance'. Soc. Stud. Sci. 2014, 44, 218-242. [CrossRef]

102. Suhay, E.; Druckman, J.N. The Politics of Science: Political Values and the Production, Communication, and Reception of Scientific Knowledge Introduction. Ann. Am. Acad. Political Soc. Sci. 2015, 658, 6-15. [CrossRef]

103. Kincheloe, J.L. Critical pedagogy and the knowledge wars of the twenty-first century. In Key Works in Critical Pedagogy; Springer: Berlin/Heidelberg, Germany, 2011; pp. 385-405.

104. Crooks, V.A.; Dorn, M.L.; Wilton, R.D. Emerging scholarship in the geographies of disability. Health Place 2008, 14, 883-888. [CrossRef]

105. Prince, M.J. Reconsidering Knowledge and Power: Reflections on Disability Communities and Disability Studies in Canada. Can. J. Disabil. Stud. 2016, 5, 1-30. [CrossRef]

106. Gerritsen, A.L.; Stuiver, M.; Termeer, C.J. Knowledge governance: An exploration of principles, impact, and barriers. Sci. Public Policy 2013, 40, 604-615. [CrossRef]

107. van der Molen, F. How knowledge enables governance: The coproduction of environmental governance capacity. Environ. Sci. Policy 2018, 87, 18-25. [CrossRef]

108. Foss, N.J.J.O. The emerging knowledge governance approach: Challenges and characteristics. Organization 2007, 14, 29-52. [CrossRef]

109. Tsao, J.; Boyack, K.; Coltrin, M.; Turnley, J.; Gauster, W. Galileo's stream: A framework for understanding knowledge production. Res. Policy 2008, 37, 330-352. [CrossRef]

110. Jacob, M.; Hellström, T. Epistemic governance and the conditions for knowledge production in HER institutions. Stud. High. Educ. 2018, 43, 1711-1717. [CrossRef]

111. Grant, M.J.; Booth, A. A typology of reviews: An analysis of 14 review types and associated methodologies. Health Inf. Libr. J. 2009, 26, 91-108. [CrossRef] [PubMed]

112. Davis, K.; Drey, N.; Gould, D. What are scoping studies? A review of the nursing literature. Int. J. Nurs. Stud. 2009, 46, 1386-1400. [CrossRef] [PubMed]

113. Arksey, H.; O'Malley, L. Scoping studies: Towards a methodological framework. Int. J. Soc. Res. Methodol. 2005, 8, 19-32. [CrossRef]

114. Levac, D.; Colquhoun, H.; O’Brien, K.K. Scoping studies: Advancing the methodology. Implement. Sci. 2010, 5, 69. [CrossRef]

115. Hsieh, H.-F.; Shannon, S.E. Three approaches to qualitative content analysis. Qual. Health Res. 2005, 15, 1277-1288. [CrossRef]

116. Edling, S.; Mooney Simmie, G. Democracy and emancipation in teacher education: A summative content analysis of teacher educators' democratic assignment expressed in policies for Teacher Education in Sweden and Ireland between 2000-2010. Citizsh. Soc. Econ. Educ. 2017, 17, 20-34. [CrossRef]

117. Braun, V.; Clarke, V. Successful Qualitative Research: A Practical Guide for Beginners; Sage: Thousand Oaks, CA, USA, 2013.

118. Clarke, V.; Braun, V. Thematic analysis. In Encyclopedia of Critical Psychology; Teo, T., Ed.; Springer: New York, NY, USA, 2014; pp. 1947-1952.

119. Downe-Wamboldt, B. Content analysis: Method, applications, and issues. Health Care Women Int. 1992, 13, 313-321. [CrossRef] 
120. Baxter, P.; Jack, S. Qualitative case study methodology: Study design and implementation for novice researchers. Qual. Rep. 2008, 13, 544-559.

121. Lincoln, Y.S.; Guba, E.G. Naturalistic Inquiry; SAGE Publications: Beverly Hills, CA, USA, 1985.

122. Shenton, A.K. Strategies for ensuring trustworthiness in qualitative research projects. Educ. Inf. 2004, 22, 63-75. [CrossRef]

123. Majocha, M.; Davenport, Z.; Braun, D.C.; Gormally, C. "Everyone was nice ... but I was still left out": An interview study about deaf interns' research experiences in STEM. J. Microbiol. Biol. Educ. 2019, 19. [CrossRef] [PubMed]

124. Gehret, A.U.; Trussell, J.W.; Michel, L.V. Approaching Undergraduate Research with Students Who Are Deaf and Hard-of-Hearing. J. Sci. Educ. Stud. Disabil. 2017, 20, 20-35.

125. Listman, J.D.; Dingus-Eason, J. How to be a Deaf scientist: Building navigational capital. J. Divers. High. Educ. 2018, 11, 279-294. [CrossRef]

126. Langley-Tumbaugh, S.; Whitney, J.; Lovewell, L.; Moeller, B. Benefits of Research Fellowships for Undergraduates with Disabilities. Counc. Undergrad. Res. Q. 2014, 35, 39-45.

127. Searle, K.A.; Ellis, L.; Kourti, M.; MacLeod, A.; Lear, C.; Duckworth, C.; Irvine, D.; Jones, H.; King, M.; Ling, J. Participatory autism research with students at a UK university: Evidence from a small-scale empirical project. Adv. Autism 2019, 5, 84-93. [CrossRef]

128. Hain, C.C.; Turek, W.C.; Zaghi, A.E.; Hain, A. Experiences of Pre-College Teachers Working with Undergraduate Engineering Students with ADHD in Research Laboratories. In Proceedings of the ASEE Annual Conference and Expositio, Columbus, OH, USA, 24-26 June 2017.

129. Weatherton, Y.P.; Mayes, R.D.; Villanueva-Perez, C. Barriers to persistence for engineering students with disabilities. In Proceedings of the ASEE Annual Conference and Exposition, Conference Proceedings, Columbus, OH, USA, 1 June 2017.

130. Atchison, C.L.; Feig, A.D. Theoretical perspectives on constructing experience through alternative field-based learning environments for students with mobility impairments. Qual. Inq. Geosci. Educ. Res. 2011, 44, 11-21.

131. Carabajal, I.G.; Marshall, A.M.; Atchison, C.L. A synthesis of instructional strategies in geoscience education literature that address barriers to inclusion for students with disabilities. J. Geosci. Educ. 2017, 65, 531-541. [CrossRef]

132. Caran, K.; MacDonald, G. Summer REU program integrating deaf and hearing participants in chemistry research. In Proceedings of the Annual Conference of the American Chemical Society, Washington, DC, USA, 20-24 August 2017.

133. Pagano, T.; Ross, A.; Smith, S. Undergraduate research involving deaf and hard-of-hearing students in interdisciplinary science projects. Educ. Sci. 2015, 5, 146-165. [CrossRef]

134. Hain, A.; Zaghi, A.E.; Taylor, C.L. Board 164: Promoting Neurodiversity in Engineering through Undergraduate Research Opportunities for Students with ADHD. In Proceedings of the 2018 ASEE Annual Conference \& Exposition, Salt Lake City, UT, USA, 13-24 June 2018.

135. Goldberg, M.R.; Cooper, R.A.; Ding, D.; Koontz, A. Using experiential learning to inspire, educate, and empower underrepresented undergraduates in STEM. In Proceedings of the ASEE Annual Conference and Exposition, Vancouver, BC, Canada, 26-29 June 2011.

136. Wolsey, J.L.A.; Dunn, K.M.; Gentzke, S.W.; Joharchi, H.A.; Clark, M.D.; The, C.T. Deaf/hearing research partnerships. Am. Ann. Deaf 2017, 161, 571-582. [CrossRef]

137. Thurston, L.P.; Shuman, C.; Middendorf, B.J.; Johnson, C. Postsecondary STEM Education for Students with Disabilities: Lessons Learned from a Decade of NSF Funding. J. Postsecond. Educ. Disabil. 2017, 30, 49-60.

138. Dutta, A.; Kang, H.J.; Kaya, C.; Benton, S.F.; Sharp, S.E.; Chan, F.; Cardoso, E.D.S.; Kundu, M. Social-cognitive career theory predictors of STEM career interests and goal persistence in minority college students with disabilities: A path analysis. J. Vocat. Rehabil. 2015, 43, 159-167. [CrossRef]

139. Braun, D.C.; Gormally, C.; Clark, M.D. The deaf mentoring survey: A community cultural wealth framework for measuring mentoring effectiveness with underrepresented students. CBE Life Sci. Educ. 2017, 16. [CrossRef] [PubMed]

140. Rand, J. Researching undergraduate social science research. Teach. High. Educ. 2016, 21, 773-789. [CrossRef]

141. Weinberg, A.E.; Trott, C.D.; Sample McMeeking, L.B. Who produces knowledge? Transforming undergraduate students' views of science through participatory action research. Sci. Educ. 2018, 102, 1155-1175. [CrossRef] 
142. Trott, C.D.; Sample McMeeking, L.B.; Weinberg, A.E. Participatory action research experiences for undergraduates: Forging critical connections through community engagement. Stud. High. Educ. 2019. [CrossRef]

143. Hansen, A.M.W.; Muñoz, J.; Crist, P.A.; Gupta, J.; Ideishi, R.I.; Primeau, L.A.; Tupé, D. Service learning: Meaningful, community-centered professional skill development for occupational therapy students. Occup. Ther. Health Care 2007, 21, 25-49. [CrossRef] [PubMed]

144. Reis, P. Promoting students' collective socio-scientific activism: Teachers' perspectives. In Activist Science and Technology Education; Springer: Berlin/Heidelberg, Germany, 2014; pp. 547-574.

145. Fairley, J.; Conrad, L.; May, G. The importance of graduate mentors in undergraduate research programs. In Proceedings of the ASEE Annual Conference and Exposition, Honolulu, HI, USA, 24-27 June 2007.

146. Jassemnejad, B.; Handy, T.A.; Murphy, S.L.; Lemley, E.C. Mentoring of freshmen STEM engineering students by senior engineering students. In Proceedings of the ASEE Annual Conference and Exposition, Austin, TX, USA, 14-17 June 2009.

147. Segura, D.; Mohorn-Mintah, O. Reflections on Undergraduate Science Experiences: A Push to Science Teaching. In Critical Voices in Science Education Research: Narratives of Hope and Struggle; Bazzul, J., Siry, C., Eds.; Springer International Publishing: Cham, Switzerland, 2019; pp. 47-58. [CrossRef]

148. Jimenez, M.F.; Laverty, T.M.; Bombaci, S.P.; Wilkins, K.; Bennett, D.E.; Pejchar, L. Underrepresented faculty play a disproportionate role in advancing diversity and inclusion. Nat. Ecol. Evol. 2019, 3, 1030-1033. [CrossRef]

149. Stanford, J.S.; Rocheleau, S.E.; Smith, K.P.W.; Mohan, J. Early undergraduate research experiences lead to similar learning gains for STEM and Non-STEM undergraduates. Stud. High. Educ. 2017, 42, 115-129. [CrossRef]

150. Zhang, C.; Swaid, S. Undergraduate Research Experience for STEM Students: Efforts and Outcomes. Contemp. Issues Educ. Res. 2017, 10, 213-218. [CrossRef]

151. National Educational Association of Disabled Students. Success in STEM Results of the Project Research Phase. Available online: http://www.neads.ca/en/about/projects/stem/stem_Research.php (accessed on 26 August 2019).

152. National Educational Association of Disabled Students (NEADS). Comparison of STEM and Non-STEM Graduate Students with Disabilities Using The Canadian Graduate and Professional Student Survey. 2016. Available online: https://www.neads.ca/en/about/media/index.php?id=678 (accessed on 26 August 2019).

153. Chand, P.; Assaf, M.H.; Jannif, I. Implication of curricula design on engineering education. In Proceedings of the IEEE International Conference on Teaching, Assessment, and Learning for Engineering (TALE), Hong Kong, China, 20-23 August 2012.

154. Covert, E.E. Engineering education in the'90 s: Back to basics. AEROSP AM 1992, 30, $20-23$.

155. Wolbring, G.; Diep, L. The Discussions around Precision Genetic Engineering: Role of and Impact on Disabled People. Laws 2016, 5, 37. [CrossRef]

156. Wolbring, G. Employment, disabled people and robots: What is the narrative in the academic literature and Canadian newspapers? Societies 2016, 6, 15. [CrossRef]

157. Blades, D.W. Levinas and an ethics for science education. Educ. Philos. Theory 2006, 38, 647-664. [CrossRef]

158. Longmore, P.K. A note on language and the social identity of disabled people. Am. Behav. Sci. 1985, 28, 419-423. [CrossRef]

159. Ohajunwa, C.; McKenzie, J.; Lorenzo, T. Enabling disability inclusive practices within the University of Cape Town curriculum: A case study. Afr. J. Disabil. 2015, 4. [CrossRef]

160. Barnes, C. Disability, Higher Education and the Inclusive Society. Br. J. Sociol. Educ. 2007, 28, 135-145. [CrossRef]

161. Traustadóttir, R.; Sigurjónsdóttir, H.B.; Egilson, S.T. Disability Studies in Iceland: Past, present and future. Scand. J. Disabil. Res. 2013, 15, 55-70. [CrossRef]

162. Furman, J.L.; Jensen, K.; Murray, F. Governing knowledge in the scientific community: Exploring the role of retractions in biomedicine. Res. Policy 2012, 41, 276-290. [CrossRef]

163. Fazekas, M.; Burns, T. Interaction Between Governance and Knowledge in Education", OECD Education Working Papers, No. 67. Available online: https://www.oecd-ilibrary.org/docserver/5k9flcx21340-en. pdf?expires $=1551548551 \&$ id $=$ id\&accname $=$ guest\&checksum $=$ A2314F88C10EF6D7B470ECBC1537029F (accessed on 26 August 2019). 
164. Tadajewski, M. Academic labour, journal ranking lists and the politics of knowledge production in marketing. J. Mark. Manag. 2016, 32. [CrossRef]

165. Parkhurst, J. The Politics of Evidence: From Evidence-Based Policy to the Good Governance of Evidence; Routledge: Abingdon, Oxon, UK, 2017.

166. Swartz, L. Disability and Citizenship in the Global South in a Post-truth Era. In The Palgrave Handbook of Disability and Citizenship in the Global South; Watermeyer, B., McKenzie, J.L.S., Eds.; Palgrave Macmillan: Cham, Switzerland, 2019; pp. 57-65. [CrossRef]

167. Brown, L.; Boardman, F.K. Accessing the field: Disability and the research process. Soc. Sci. Med. 2011, 72, 23-30. [CrossRef] [PubMed]

168. Parent, L. The wheeling interview: Mobile methods and disability. Mobilities 2016, 11, 521-532. [CrossRef]

169. Polczyk, P. Autoethnography as an Accessible Method of Research. Available online: https://core.ac.uk/ download/pdf/51278858.pdf (accessed on 26 August 2019).

170. Shah, S. Sharing the world: The researcher and the researched. Qual. Res. 2006, 6, 207-220. [CrossRef]

171. Taylor, A. Making Disability (Matter) in Philosophy of Education. Philos. Educ. Arch. 2015, 20, $224-232$.

172. Bader, V. Sciences, politics, and associative democracy: Democratizing science and expertizing democracy. Innovation 2014, 27, 420-441. [CrossRef]

173. Penders, B. Biotechnology: DIY biology. Nature 2011, 472, 167. [CrossRef]

174. Greenwood, D.J. Teaching/learning action research requires fundamental reforms in public higher education. Action Res. 2007, 5, 249-264. [CrossRef]

175. Radermacher, H.; Sonn, C.; Keys, C.; Duckett, P. Disability and participation: It's about us but still without us! J. Community Appl. Soc. Psychol. 2010, 20, 333-346. [CrossRef]

176. Wandersman, A. Community Science: Bridging the Gap between Science and Practice with Community-Centered Models. Am. J. Community Psychol. 2003, 31, 227-242. [CrossRef]

177. du Toit, S.; Wilkinson, A. Promoting an appreciation for research-related activities: The role of occupational identity. Br. J. Occup. Ther. 2011, 74, 489-493. [CrossRef]

(C) 2019 by the authors. Licensee MDPI, Basel, Switzerland. This article is an open access article distributed under the terms and conditions of the Creative Commons Attribution (CC BY) license (http://creativecommons.org/licenses/by/4.0/). 